\title{
Intraoperative cholangiography in the laparoscopic cholecystectomy era: why are we still debating?
}

\author{
F. Ausania $\cdot$ L. R. Holmes $\cdot$ F. Ausania $\cdot$ \\ S. Iype $\cdot$ P. Ricci $\cdot$ S. A. White
}

Received: 7 December 2011 / Accepted: 1 March 2012/Published online: 22 March 2012

(C) Springer Science+Business Media, LLC 2012

\begin{abstract}
Laparoscopic cholecystectomy is now one of the most frequently performed abdominal surgical procedures in the world. The most common major complication is bile duct injury, which can have catastrophic repercussions for patients and it has been suggested that intraoperative cholangiography may reduce the rate of bile duct injury. Whether this procedure should be performed routinely is still an active subject of debate. We discuss the available evidence and likely implications for the future.
\end{abstract}

Keywords Hepato... (Liver)

The first laparoscopic cholecystectomy (LC) was performed in September 1985 by Erich Muhe [1]. Although the surgical community was initially unconvinced about the significance of this new technique, it is now the most frequently performed abdominal surgical procedure, and one of the most common operations in Europe and the United States [2].

Morbidity has been reported as 2-4\%, whereas the incidence of major complications that require urgent operative management is much lower $[2,3]$. The most common major complication is bile duct injury (BDI), with published rates as high as $1.4 \%$, although the literature

F. Ausania $(\square) \cdot$ L. R. Holmes $\cdot$ S. A. White HPB Surgery, Freeman Hospital, Newcastle Upon Tyne NE77DN, UK

e-mail: f.ausania@googlemail.com

F. Ausania $\cdot$ P. Ricci

Forensic Medicine, Magna Graecia University, Catanzaro, Italy

S. Iype

Upper GI Surgery, Ipswich Hospital, Ipswich, UK more commonly reports incidence as $0.15-0.6 \%$, approximately one per 200 procedures [2-9]. In contrast, the incidence of BDI after open cholecystectomy (OC) is reported as $0.1-0.3 \%$, an equivalent nearer to one per 500 cases $[10,11]$. Traditionally, surgeons opt for operations with lower complication rates, and the "learning curve" was one of the arguments to account for the increased incidence of BDIs during LC [12]. However, further publications have reported that this incidence remains higher even when "learning curve" is accounted for [4, 13, 14], even in light of technological advances that have improved visualization and instrumentation [14-18]. Despite this evidence, LC remains the treatment of choice for symptomatic gallstones, a fact most likely attributable to the benefits of less postoperative pain, shorter hospital stay, better cosmetic result, and increased patient satisfaction $[12,19-22]$. In fact, the number of cholecystectomies in the United Kingdom has nearly doubled during the past decade (Fig. 1).

\section{Bile duct injury: mechanism, classification,} and consequences

Davidoff et al. described "classical laparoscopic BDI" as misinterpretation of the common bile duct (CBD) or hepatic duct, as the cystic duct, resulting in clipping and division [23]. Several mechanisms for laparoscopic ductal injury can be identified, including tenting and diathermy injuries [7]. Dissection of the hilum of the liver can result in injury of more proximal hepatic ducts; nonetheless, the causes leading to BDI often are multifactorial. These causes include excessive bleeding, poor visualization of the field, inflammation, poor illumination, lack of awareness 
Fig. 1 Number of total cholecystectomies in the United Kingdom (Source: Hospital Episode Statistics)

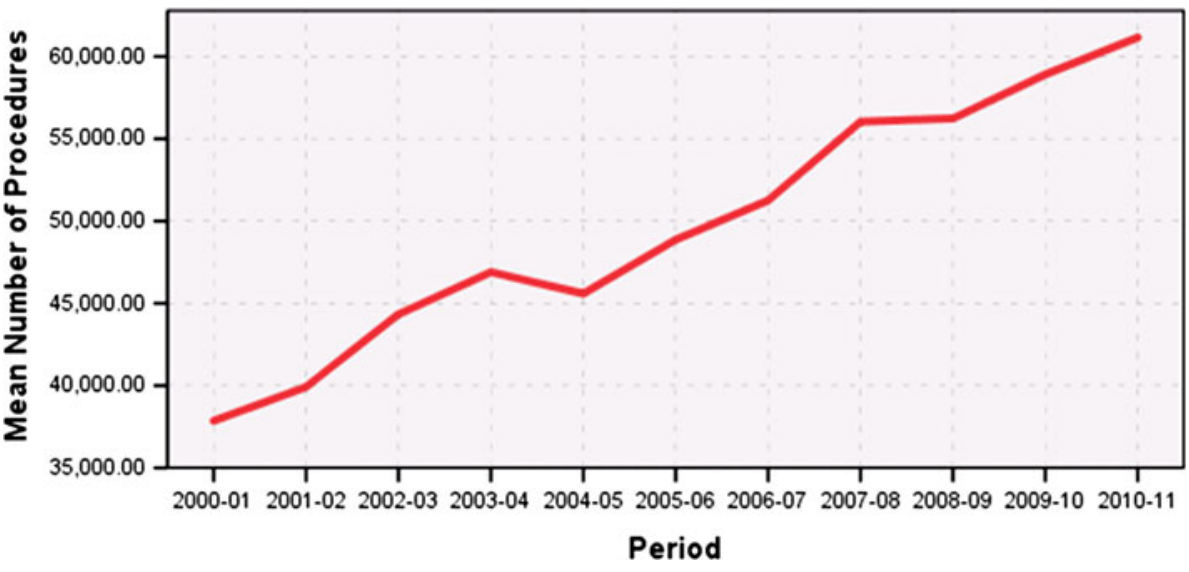

about the orientation of bile duct anatomy, anatomical abnormalities, and surgical incompetence.

There are several classifications for BDI. Bismuth's classification (Type $\mathrm{I}-\mathrm{V}$ ) of $\mathrm{BDI} /$ stricture precluded the advent of LC but helped surgeons to choose the type of repair and correlated well with outcome [24, 25]. McMahon et al. [26] then further subdivided the type of BDI into laceration, transection, or excision, while retaining Bismuths classification to grade the level of the stricture. Minor and major injuries also were distinguished for the purposes of management; minor required a simple suture repair and/or insertion of a T-tube, whereas a hepaticojejunostomy was recommended to treat a major injury [26]. Strasberg's classification (Type A-E) is a comprehensive modification of Bismuth's classification that includes various other types of laparoscopic extrahepatic BDIs [11]. Various other systems have since been proposed by Bergman et al. [27], Neuhaus et al. [28], Csendes et al. [29], Stewart et al. [30], and Lau et al. [31] in an effort to describe all possible lesions (Table 1). Recently Cannon et al. [32] have reported criteria to aid in predicting the financial cost of a particular insult and when referral to a tertiary hepatobiliary center is appropriate.

BDI causes serious consequences for the patient, which is compounded by any delay in the recognition of an insult or if a repair is attempted by an inexperienced surgeon [33]. Several authors have reported alarming outcomes for BDI repair, and in some series, mortality and morbidity for biliodigestive reconstruction after injury are as high as $8.6 \%$ and $42 \%$ respectively [34]. Even in the event of a successful repair, subsequent morbidity is significant and the sequelae include symptomatic adhesions, recurrent cholangitis, abscess, strictures, secondary biliary cirrhosis, and chronic liver disease [3, 35-40]. In extreme cases, a liver transplant may be required as a direct result of BDI complications [41-43]. As well as these physical complications, BDI also has been shown to impact a patient's quality of life and life expectancy significantly, often even after successful repair [44, 45]. The poor outcome after BDI often is determined by the severity and level of the injury during LC. Ludwig et al. found that the most common lesions are type $\mathrm{C}$ and $\mathrm{D}$ according to the Neuhaus classification, injuries that often can require a biliodigestive anastomosis, which confers significant morbidity and mortality [9]. Lillemoe et al. [46] also compared BDIs sustained during $\mathrm{LC}$ versus $\mathrm{OC}$ and found that the injuries associated with LC tended to be more complex, with more than $60 \%$ classified as Bismuth 3 or higher compared with only $40 \%$ of this severity as a result of OC.

\section{Role of intraoperative cholangiogram (IOC): a literature overview}

In the past many attempts have been made to reduce the rate of BDI. Among these, IOC is probably the most commonly used, as well as the most debated. This technique, originally described by Mirizzi in 1931 [47], involves endoscopic cannulation of the cystic duct to visualize the bile duct. This allows the identification of any bile duct stones or preexisting anatomic abnormalities, as well as highlighting iatrogenic injuries that may have occurred [2].

IOC was historically utilized in open procedures to aid CBD stone detection and its routine use was debated long before the birth of LC [48]. However, IOC during LC provides the additional benefit of providing a "road map" for operative dissection. Some institutions use IOC routinely to identify CBD stones, provide extra evidence for anatomical decisions during dissection, training purposes, and to highlight biliary injury should it occur. The selective use of IOC is based on individual surgeon/institution policy, because no reliable standardized criteria exist [49], and often is used to help clarify difficult anatomy or highlight CBD stones if they are suspected. If stones are highlighted, they can be treated at the time in a single operation, which 


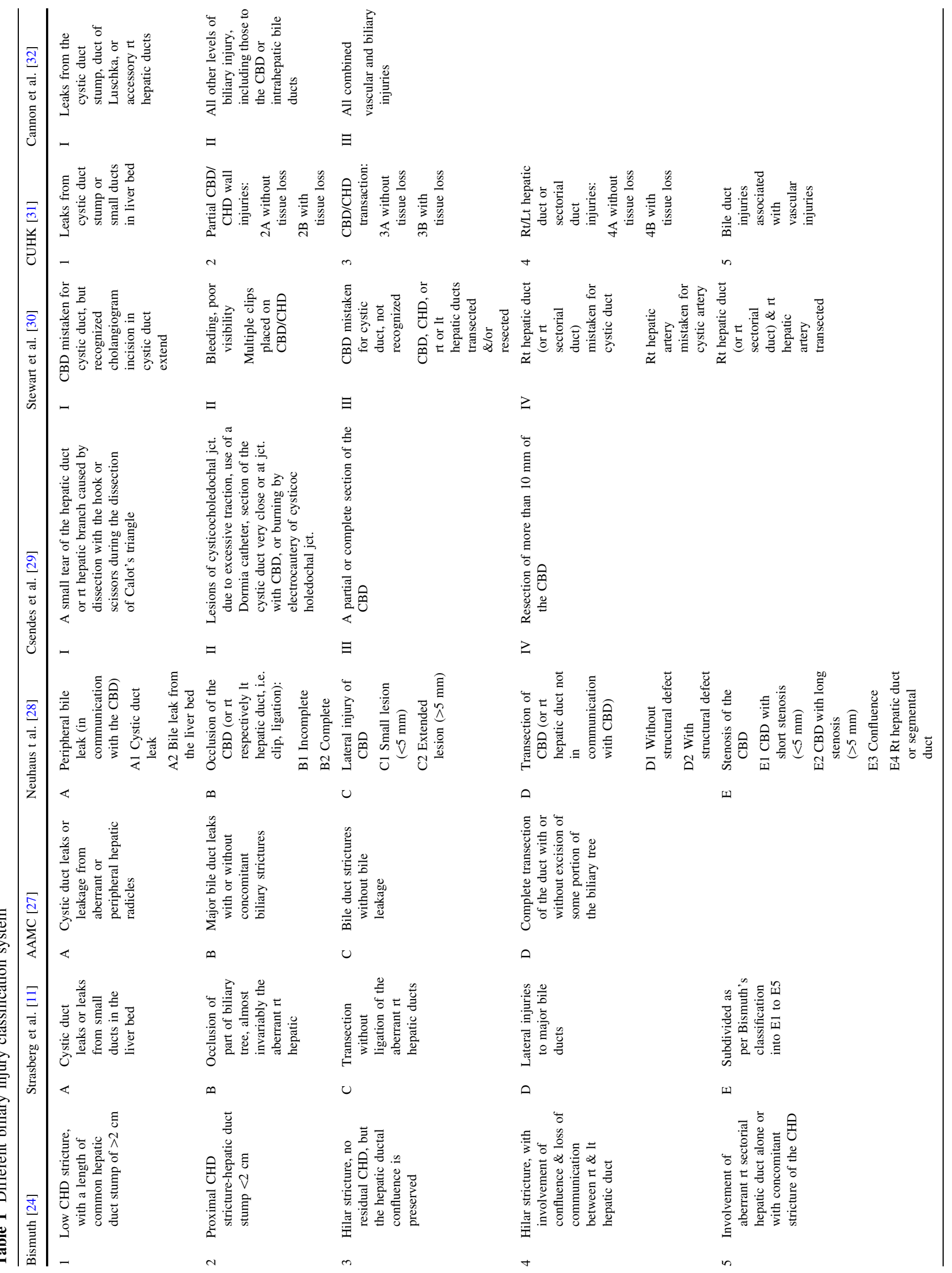


decreases the use of unnecessary, nontherapeutic, endoscopic retrograde cholangiopancreatography (ERCP) [50, 51].

The role of IOC has been extensively investigated, and several national surveys have been published (Table 1). The results are controversial, often biased by retrospective data collection, poor data quality (mostly based on questionnaires or data codes), and impossibility to determine the intent of IOC use at the time (routine or to protect against injury, to detect CBD stones, or for suspected injury). Whether this procedure should be performed routinely is still an active subject of debate, but several of the larger retrospective studies associate a decrease in the frequency and severity of CBD injuries when an IOC is performed (Table 2) [2, 6, 52].

Several prospective studies have tried to evaluate the usefulness of IOC [53-55]; however, because BDI is such a rare event during LC (0.15-0.6\%), to demonstrate a $50 \%$ reduction in CBD injuries, more than 26,000 patients need to be included in such a trial [56]. This sample size clearly renders previously published studies inadequate in terms of assessing the effect of IOC.

The limiting factors often mentioned when debating the routine use of IOC are local resource availability, expertise to interpret cholangiograms, additional operating time, and the infrequency of BDI [61]. The incorrect interpretation of cholangiograms is probably the most important of these considerations [62, 63], and a recent evaluation of IOC found that correct biliary anatomy could only be conclusively documented in $57 \%$ of cases [64], a feat that is rendered even more difficult in the presence of cholecystitis. Conflicting reports exist about the usefulness of IOC for the identification of biliary anatomy when there is significant scarring or inflammation in the triangle of Calot $[61,64]$. Adequate resolution of the anatomy is imperative so that injuries can be identified to permit successful repair. Stewart et al. [65] reported that $69 \%$ of repairs were not successful when the cholangiographic data were incomplete. In contrast, the initial repair was successful in $84 \%$ of patients when IOC data was complete. This required level of competence, in technique and interpretation, might be linked to why surgeons performing IOC routinely have more favorable opinions about its usefulness and have a corresponding lower incidence of BDI [2, 66].

Performing IOC means an increased operative time, which has been reported in the literature as $8,10,16$, and 20 min respectively [9, 58, 67, 68]. However, studies have indicated that despite the increased time in operative procedure and materials, routine IOC is cost-effective by reducing the severity of bile duct injury and the cost of treatment of patients with retained stones who did not receive IOC $[56,61,69]$.

\section{Importance of intraoperative detection of BDI}

Despite variation on opinions about the routine or selective use of IOC, it has demonstrated a reduction in the incidence of major BDI and expeditiously identifies insults at the time of surgery [2, 13, 52, 59, 70-73]. Archer et al. [13] reported that routine use of IOC increased detection of BDI from $45 \%$ to $85 \%$, which is similar to the increased detection described by Ludwig et al. [9] from $45 \%$ to $90 \%$. Intraoperative detection of a ductal injury should decrease the technical difficulty of a repair, because there is no infection, inflammation, or fibrosis in the operating field compared with a delayed repair. This will greatly reduce the subsequent morbidity that is experienced compared with delayed BDI detection, which can be catastrophic for patients. It has been described that once an injury occurs, a patient's possible mortality increases to near $18 \%[2,3]$. In addition to this significant mortality, the monetary cost of BDI repair can be 26 times that of an uncomplicated procedure, which is directly related to the increased

Table 2 Population level data showing LC use and impact of IOC on BDI incidence

\begin{tabular}{|c|c|c|c|c|c|c|}
\hline Ref. no. & Source & Inclusion period & Country & $\begin{array}{l}\text { No. of pts } \\
\text { undergoing LC }\end{array}$ & $\begin{array}{l}\text { No. of } \\
\text { BDI }(\%)\end{array}$ & $\begin{array}{l}\text { Approx. BDI risk reduction } \\
\text { if using IOC during LC }\end{array}$ \\
\hline [57] & Regöly-Mérei J & 1991-1994 & Hungary & $26,440^{\mathrm{a}}$ & $148(0.56)$ & No effect observed \\
\hline$[58]$ & Z'graggen $\mathrm{K}$ & $1992-1995$ & Switzerland & 10,174 & $32(0.31)$ & $\begin{array}{l}\text { Did not reduce risk of BDI but improved } \\
\text { diagnosis of intraoperative BDI }\end{array}$ \\
\hline$[59]$ & Fletcher D & $1988-1994$ & Australia & 7,675 & $25(0.33)$ & $>50 \% \downarrow$ risk, eightfold if complex case \\
\hline$[6]$ & Flum DR & $1991-1997$ & USA & 30,630 & $76(0.25)$ & $40 \% \downarrow$ risk \\
\hline$[2]$ & Flum DR & 1992-1999 & USA & $1,570,361^{\mathrm{b}}$ & $7911(0.5)$ & $50-70 \% \downarrow$ risk \\
\hline$[60]$ & Nuzzo G & $1998-2000$ & Italy & 56,591 & $235(0.42)$ & $\begin{array}{l}\text { No significant risk reduction observed } \\
\text { between routine and selective IOC }\end{array}$ \\
\hline [52] & Waager A & 1987-2001 & Sweden & $152,776^{\mathrm{c}}$ & $613(0.4)$ & $34 \% \downarrow$ risk \\
\hline
\end{tabular}

${ }^{\mathrm{a}}$ IOC in only $6.9 \%$ of cases; ${ }^{\mathrm{b}}>75 \%$ were $\mathrm{LCs} ;{ }^{\mathrm{c}}$ LCs and OCs were not differentiated 
morbidity, mortality, length of hospitalization, and number of outpatient care days [46, 74].

\section{Medicolegal implications}

More than half a million LCs are performed each year in the United States as standard treatment of gallbladder disease, whereas more than 55,000 are undertaken annually in England, making it one of the most commonly performed surgical procedures [75, 76]. Complications are relatively rare; however, this volume of patients mean that a significant number of people suffer an iatrogenic injury at the time of the procedure (Table 2). BDI is the most common of these to involve litigation; most studies indicate that it accounts for 60-72\% of all claims following LC (Table 3). In the United States, BDI injury is the leading cause of medical negligence claims against general surgeons and LC is associated with 20 -fold more litigation compared with OC $[77,78]$. It also is a significant reason for litigation in Europe [79, 80]; in England alone during the past 15 years, legal action has cost the NHS in excess of 20 million GBP [81]. Data from the National Health Service Litigation Authority (NHSA) on clinical negligence indicate that, as a whole, the organization is receiving more claims each year and 2009/2010 recorded an annual increase of $31.6 \%$ [82]. This corresponded to a $12 \%$ increase in total expenditure on claims from 651 to 729 million GBP [82].

Three main reasons have been previously outlined that not only contribute to a claim being made but also to a large monetary sum being awarded [78, 81, 85]: high earnings loss, patient disability or death, and a feeling by the patient that negligence is responsible. Delay in diagnosis of BDI contributes to both of these latter issues and is reported to occur in more than $80 \%$ of cases, therefore strongly correlating with an increased risk of litigation [16, $18,79,83-85]$. IOC allows early identification of a BDI as discussed, so it can significantly ameliorate patient morbidity and mortality, as well as have a protective effect against malpractice litigation [78].

\section{Final considerations}

It is clear that IOC is not a fail-safe technique against BDI. Surgeons must understand the nuances of interpretation if they are going to perform the technique and obtain an experienced opinion when unsure $[63,88]$. Whether IOC in LC should become routine will continue to remain a contentious issue. The statement that "no persistently reliable intraoperative criteria" upon which a selective IOC policy can be based adds weight to the argument for routine [49]. Also, the collective weight of evidence from several large, observational studies that IOC reduces BDI should not be ignored. This is coupled with good evidence that IOC decreases the need for reoperation and patient morbidity/ mortality if a BDI does occur by significantly reducing the degree of the insult. This evidence suggests that arguments against IOC, such as lack of resources and technical expertise, should not act as a deterrent. Rather they should be used as an argument for centralization of services and the inclusion of cholangiogram interpretation in LC training. However, a truly causal relationship between IOC and reduced $\mathrm{BDI}$ has yet to be conclusively established, which leaves the issue unresolved, probably forever.

A consideration in the argument for the implementation of routine IOC that is gaining weight is its use as a weapon in the arsenal of defensive medicine. Society is becoming increasingly litigious, and the volume of medical negligence claims is rising each year, especially in the United Kingdom [82]. Currently, it is estimated that $16 \%$ of BDIs in England result in malpractice claims, but this number continues to close on the United States' rate of $\approx 30 \%$ [85]. These rising figures and large settlements mean that routine IOC has been reported to be cost effective due to its

Table 3 Comparison of litigation data following LC

\begin{tabular}{lllllllll}
\hline Ref. no. & Source & Period & Country & $\begin{array}{l}\text { No. } \\
\text { cases }\end{array}$ & \% BDI & $\begin{array}{l}\text { \% Vascular } \\
\text { injury }\end{array}$ & $\begin{array}{l}\text { \% bowel } \\
\text { injury }\end{array}$ & $\begin{array}{l}\text { Av. payout (USD } \\
\text { to nearest thousand) }\end{array}$ \\
\hline$[78]$ & Kern & $1989-1992$ & USA & 44 & 61 & 9 & 16 & 438 \\
{$[86]$} & Chandler & $1989-1993$ & USA & 306 & 66 & 6 & 8 & $160-223$ \\
{$[83]$} & PIAA & $1990-1993$ & USA & 324 & 70 & 9 & 78 & 136 \\
{$[18]$} & McLean & $1999-2004$ & USA & 104 & 78 & 7 & 2 & 508 \\
{$[87]$} & Griffen & $2004-2006$ & USA & 88 & $\approx 60$ & N/A & N/A & N/A \\
{$[81]$} & Alkhaffaf & $1995-2009$ & England & 418 & 43 & 10 & 11 & 168 \\
{$[85]$} & Roy & $2000-2005$ & England & 133 & 72 & 3 & 9 & 84 \\
{$[79]$} & De Reuver & $1994-2006$ & Holland & 210 & 62 & N/A & N/A & 18 \\
\hline
\end{tabular}


early detection of BDI as discussed [56, 61]. A recent study investigating medicolegal claims following laparoscopic cholecystectomy in the United Kingdom and Ireland concluded that BDI is "almost indefensible" [89]. This statement means that although the protective effects of IOC against BDI continue to be debated in the absence of definitive evidence, the undeniable fact that IOC does reduce the cost of litigation will likely gain increasing gravitas with time, culminating in health organizations instigating routine IOC during LC for economic reasons.

Disclosures Drs. Fabio Ausania, Luke Homes, Francesco Ausania, Satheesh Iype, Pietrantonio Ricci, and Steven White have no conflict of interest or financial ties to disclose.

\section{References}

1. Muhe E (1991) [Laparoscopic cholecystectomy-late results]. Langenbecks Archiv fur Chirurgie Supplement Kongressband Deutsche Gesellschaft fur Chirurgie Kongress. Laparoskopische Cholezystektomie-Spatergebnisse. p 416-723

2. Flum DR, Dellinger EP, Cheadle A, Chan L, Koepsell T (2003) Intraoperative cholangiography and risk of common bile duct injury during cholecystectomy. JAMA 289(13):1639-1644

3. Deziel DJ, Millikan KW, Economou SG, Doolas A, Ko ST, Airan MC (1993) Complications of laparoscopic cholecystectomy: a national survey of 4,292 hospitals and an analysis of 77,604 cases. Am J Surg 165(1):9-14

4. Calvete J, Sabater L, Camps B, Verdu A, Gomez-Portilla A, Martin J et al (2000) Bile duct injury during laparoscopic cholecystectomy: myth or reality of the learning curve? Surg Endosc 14(7):608-611

5. Dolan JP, Diggs BS, Sheppard BC, Hunter JG (2005) Ten-year trend in the national volume of bile duct injuries requiring operative repair. Surg Endosc 19(7):967-973

6. Flum DR, Koepsell T, Heagerty P, Sinanan M, Dellinger EP (2001) Common bile duct injury during laparoscopic cholecystectomy and the use of intraoperative cholangiography: adverse outcome or preventable error? Arch Surg 136(11):1287-1292

7. Richardson MC, Bell G, Fullarton GM (1996) Incidence and nature of bile duct injuries following laparoscopic cholecystectomy: an audit of 5913 cases. West of Scotland Laparoscopic Cholecystectomy Audit Group. Br J Surg 83(10):1356-1360

8. Walsh RM, Henderson JM, Vogt DP, Mayes JT, GrundfestBroniatowski S, Gagner M et al (1998) Trends in bile duct injuries from laparoscopic cholecystectomy. J Gastrointest Surg 2(5):458-462

9. Ludwig K, Bernhardt J, Steffen H, Lorenz D (2002) Contribution of intraoperative cholangiography to incidence and outcome of common bile duct injuries during laparoscopic cholecystectomy. Surg Endosc 16(7):1098-1104

10. Roslyn JJ, Binns GS, Hughes EF, Saunders-Kirkwood K, Zinner MJ, Cates JA (1993) Open cholecystectomy. A contemporary analysis of 42,474 patients. Ann Surg 218(2):129-137

11. Strasberg SM, Hertl M, Soper NJ (1995) An analysis of the problem of biliary injury during laparoscopic cholecystectomy. J Am Coll Surg 180(1):101-125

12. (1991) A prospective analysis of 1518 laparoscopic cholecystectomies. The Southern Surgeons Club. N Engl j Med 324(16): 1073-1078
13. Archer SB, Brown DW, Smith CD, Branum GD, Hunter JG (2001) Bile duct injury during laparoscopic cholecystectomy: results of a national survey. Ann Surg 234(4):549-558 discussion 558-559

14. Windsor JA, Pong J (1998) Laparoscopic biliary injury: more than a learning curve problem. Aust N Z J Surg 68(3):186-189

15. Cohen MM, Young W, Theriault ME, Hernandez R (1996) Has laparoscopic cholecystectomy changed patterns of practice and patient outcome in Ontario? CMAJ 154(4):491-500

16. Connor S, Garden OJ (2006) Bile duct injury in the era of laparoscopic cholecystectomy. Br J Surg 93(2):158-168

17. Hugh TB (2002) New strategies to prevent laparoscopic bile duct injury-surgeons can learn from pilots. Surgery 132(5):826-835

18. McLean TR (2006) Risk management observations from litigation involving laparoscopic cholecystectomy. Arch Surg 141(7): 643-648 discussion 648

19. Barkun JS, Barkun AN, Sampalis JS, Fried G, Taylor B, Wexler MJ et al (1992) Randomised controlled trial of laparoscopic versus mini cholecystectomy. The McGill Gallstone Treatment Group. Lancet 340(8828):1116-1119

20. Berci G, Sackier JM (1991) The Los Angeles experience with laparoscopic cholecystectomy. Am J Surg 161(3):382-384

21. McMahon AJ, Russell IT, Baxter JN, Ross S, Anderson JR, Morran CG et al (1994) Laparoscopic versus minilaparotomy cholecystectomy: a randomised trial. Lancet 343(8890):135-138

22. Robinson TN, Stiegmann GV (2004) Minimally invasive surgery. Endoscopy 36(1):48-51

23. Davidoff AM, Pappas TN, Murray EA, Hilleren DJ, Johnson RD, Baker ME et al (1992) Mechanisms of major biliary injury during laparoscopic cholecystectomy. Ann Surg 215(3):196-202

24. Bismuth $H$ (1982) Postoperative strictures of the bile ducts. In: Blumgart LH (ed) The biliary tract. Churchill Livingstone, Edinburgh

25. Bismuth H, Majno PE (2001) Biliary strictures: classification based on the principles of surgical treatment. World J Surg 25(10): 1241-1244

26. McMahon AJ, Fullarton G, Baxter JN, O’Dwyer PJ (1995) Bile duct injury and bile leakage in laparoscopic cholecystectomy. $\mathrm{Br}$ J Surg 82(3):307-313

27. Bergman JJ, van den Brink GR, Rauws EA, de Wit L, Obertop H, Huibregtse K et al (1996) Treatment of bile duct lesions after laparoscopic cholecystectomy. Gut 38(1):141-147

28. Neuhaus P, Schmidt SC, Hintze RE, Adler A, Veltzke W, Raakow $\mathrm{R}$ et al (2000) [Classification and treatment of bile duct injuries after laparoscopic cholecystectomy]. Der Chirurg; Zeitschrift fur alle Gebiete der operativen Medizen 71(2):166-173. Einteilung und Behandlung von Gallengangverletzungen nach laparoskopischer Cholecystektomie

29. Csendes A, Navarrete C, Burdiles P, Yarmuch J (2001) Treatment of common bile duct injuries during laparoscopic cholecystectomy: endoscopic and surgical management. World J Surg 25(10):1346-1351

30. Stewart L, Robinson TN, Lee CM, Liu K, Whang K, Way LW (2004) Right hepatic artery injury associated with laparoscopic bile duct injury: incidence, mechanism, and consequences. J Gastrointest Surg 8(5):523-530 discussion 530-531

31. Lau WY, Lai EC (2007) Classification of iatrogenic bile duct injury. Hepatobiliary Pancreat Dis Int 6(5):459-463

32. Cannon RM, Brock G, Buell JF (2011) A novel classification system to address financial impact and referral decisions for bile duct injury in laparoscopic cholecystectomy. HPB Surg 2011:371245

33. Flum DR, Cheadle A, Prela C, Dellinger EP, Chan L (2003) Bile duct injury during cholecystectomy and survival in medicare beneficiaries. JAMA 290(16):2168-2173

34. Sicklick JK, Camp MS, Lillemoe KD, Melton GB, Yeo CJ, Campbell KA et al (2005) Surgical management of bile duct injuries sustained during laparoscopic cholecystectomy: perioperative 
results in 200 patients. Ann Surg 241(5):786-792 discussion 793-795

35. Pellegrini CA, Thomas MJ, Way LW (1984) Recurrent biliary stricture. Patterns of recurrence and outcome of surgical therapy. Am J Surg 147(1):175-180

36. Pitt HA, Miyamoto T, Parapatis SK, Tompkins RK, Longmire WP Jr (1982) Factors influencing outcome in patients with postoperative biliary strictures. Am J Surg 144(1):14-21

37. Trerotola SO, Savader SJ, Lund GB, Venbrux AC, Sostre S, Lillemoe KD et al (1992) Biliary tract complications following laparoscopic cholecystectomy: imaging and intervention. Radiology 184(1):195-200

38. Birkett DH (1995) Spilled cells, spilled clips, spilled stones. New problems or old challenges. Surg Endosc 9(3):269-271

39. Walsh RM, Henderson JM, Vogt DP, Brown N (2007) Long-term outcome of biliary reconstruction for bile duct injuries from laparoscopic cholecystectomies. Surgery 142(4):450-456 discussion 456-457

40. Schmidt SC, Langrehr JM, Hintze RE, Neuhaus P (2005) Longterm results and risk factors influencing outcome of major bile duct injuries following cholecystectomy. Br J Surg 92(1):76-82

41. Nordin A, Halme L, Makisalo H, Isoniemi H, Hockerstedt $\mathrm{K}$ (2002) Management and outcome of major bile duct injuries after laparoscopic cholecystectomy: from therapeutic endoscopy to liver transplantation. Liver Transpl 8(11):1036-1043

42. de Santibanes E, Pekolj J, McCormack L, Nefa J, Mattera J, Sivori J et al (2002) Liver transplantation for the sequelae of intra-operative bile duct injury. HPB (Oxford) 4(3):111-115

43. Oncel D, Ozden I, Bilge O, Tekant Y, Acarli K, Alper A et al (2006) Bile duct injury during cholecystectomy requiring delayed liver transplantation: a case report and literature review. Tohoku J Exp Med 209(4):355-359

44. Boerma D, Rauws EA, Keulemans YC, Bergman JJ, Obertop H, Huibregtse $\mathrm{K}$ et al (2001) Impaired quality of life 5 years after bile duct injury during laparoscopic cholecystectomy: a prospective analysis. Ann Surg 234(6):750-757

45. de Reuver PR, Sprangers MA, Rauws EA, Lameris JS, Busch OR, van Gulik TM et al (2008) Impact of bile duct injury after laparoscopic cholecystectomy on quality of life: a longitudinal study after multidisciplinary treatment. Endoscopy 40(8):637-643

46. Lillemoe KD, Melton GB, Cameron JL, Pitt HA, Campbell KA, Talamini MA et al (2000) Postoperative bile duct strictures: management and outcome in the $1990 \mathrm{~s}$. Ann Surg 232(3): 430-441

47. Mirizzi PL, Quiroza LC (1931) La exploración de las vias biliares principales en el curso de la operacion. Proc Third Argent Cong Surg 1:694

48. Way LW, Admirand WH, Dunphy JE (1972) Management of choledocholithiasis. Ann Surg 176(3):347-359

49. Cuschieri A, Shimi S, Banting S, Nathanson LK, Pietrabissa A (1994) Intraoperative cholangiography during laparoscopic cholecystectomy. Routine vs. selective policy. Surg Endosc 8(4):302-305

50. Fiore NF, Ledniczky G, Wiebke EA, Broadie TA, Pruitt AL, Goulet RJ et al (1997) An analysis of perioperative cholangiography in one thousand laparoscopic cholecystectomies. Surgery 122(4):817-821 discussion 821-823

51. Kullman E, Borch K, Lindstrom E, Svanvik J, Anderberg B (1996) Management of bile duct stones in the era of laparoscopic cholecystectomy: appraisal of routine operative cholangiography and endoscopic treatment. Eur J Surg 162(11):873-880

52. Waage A, Nilsson M (2006) Iatrogenic bile duct injury: a population-based study of 152776 cholecystectomies in the Swedish Inpatient Registry. Arch Surg 141(12):1207-1213

53. Clair DG, Carr-Locke DL, Becker JM, Brooks DC (1993) Routine cholangiography is not warranted during laparoscopic cholecystectomy. Arch Surg 128(5):551-554 discussion 554-555
54. Hauer-Jensen M, Karesen R, Nygaard K, Solheim K, Amlie EJ, Havig O et al (1993) Prospective randomized study of routine intraoperative cholangiography during open cholecystectomy: long-term follow-up and multivariate analysis of predictors of choledocholithiasis. Surgery 113(3):318-323

55. Nickkholgh A, Soltaniyekta S, Kalbasi H (2006) Routine versus selective intraoperative cholangiography during laparoscopic cholecystectomy: a survey of 2,130 patients undergoing laparoscopic cholecystectomy. Surg Endosc 20(6):868-874

56. Flum DR, Flowers C, Veenstra DL (2003) A cost-effectiveness analysis of intraoperative cholangiography in the prevention of bile duct injury during laparoscopic cholecystectomy. J Am Coll Surg 196(3):385-393

57. Regoly-Merei J, Ihasz M, Szeberin Z, Sandor J, Mate M (1998) Biliary tract complications in laparoscopic cholecystectomy. A multicenter study of 148 biliary tract injuries in 26,440 operations. Surg Endosc 12(4):294-300

58. Z'Graggen K, Wehrli H, Metzger A, Buehler M, Frei E, Klaiber C (1998) Complications of laparoscopic cholecystectomy in Switzerland. A prospective 3-year study of 10,174 patients. Swiss Association of Laparoscopic and Thoracoscopic Surgery. Surg Endosc 12(11): 1303-1310

59. Fletcher DR, Hobbs MS, Tan P, Valinsky LJ, Hockey RL, Pikora TJ et al (1999) Complications of cholecystectomy: risks of the laparoscopic approach and protective effects of operative cholangiography: a population-based study. Ann Surg 229(4):449-457

60. Nuzzo G, Giuliante F, Giovannini I, Ardito F, D'Acapito F, Vellone $\mathrm{M}$ et al (2005) Bile duct injury during laparoscopic cholecystectomy: results of an Italian national survey on 56591 cholecystectomies. Arch Surg 140(10):986-992

61. Podnos YD, Gelfand DV, Dulkanchainun TS, Wilson SE, Cao S, Ji $P$ et al (2001) Is intraoperative cholangiography during laparoscopic cholecystectomy cost effective? Am J Surg 182(6):663-669

62. Way LW, Stewart L, Gantert W, Liu K, Lee CM, Whang K et al (2003) Causes and prevention of laparoscopic bile duct injuries: analysis of 252 cases from a human factors and cognitive psychology perspective. Ann Surg 237(4):460-469

63. Woods MS, Traverso LW, Kozarek RA, Donohue JH, Fletcher DR, Hunter JG et al (1995) Biliary tract complications of laparoscopic cholecystectomy are detected more frequently with routine intraoperative cholangiography. Surg Endosc 9(10):1076-1080

64. Buddingh KT, Morks AN, Ten Cate Hoedemaker HO, Blaauw CB, van Dam GM, Ploeg RJ et al (2012) Documenting correct assessment of biliary anatomy during laparoscopic cholecystectomy. Surg Endosc 26(1):79-85

65. Stewart L, Way LW (1995) Bile duct injuries during laparoscopic cholecystectomy. Factors that influence the results of treatment. Arch Surg 130(10):1123-1128 discussion 1129

66. Massarweh NN, Devlin A, Elrod JA, Symons RG, Flum DR (2008) Surgeon knowledge, behavior, and opinions regarding intraoperative cholangiography. J Am Coll Surg 207(6):821-830

67. Soper NJ, Brunt LM (1994) The case for routine operative cholangiography during laparoscopic cholecystectomy. Surg Clin North Am 74(4):953-959

68. Flowers JL, Zucker KA, Graham SM, Scovill WA, Imbembo AL, Bailey RW (1992) Laparoscopic cholangiography. Results and indications. Ann Surg 215(3):209-216

69. Phillips EH (1993) Routine versus selective intraoperative cholangiography. Am J Surg 165(4):505-507

70. Buddingh KT, Nieuwenhuijs VB, van Buuren L, Hulscher JB, de Jong JS, van Dam GM (2011) Intraoperative assessment of biliary anatomy for prevention of bile duct injury: a review of current and future patient safety interventions. Surg Endosc 25(8):2449-2461

71. Morgenstern L, McGrath MF, Carroll BJ, Paz-Partlow M, Berci G (1995) Continuing hazards of the learning curve in laparoscopic cholecystectomy. Am Surg 61(10):914-918 
72. Slater K, Strong RW, Wall DR, Lynch SV (2002) Iatrogenic bile duct injury: the scourge of laparoscopic cholecystectomy. ANZ J Surg 72(2):83-88

73. Olsen D (1997) Bile duct injuries during laparoscopic cholecystectomy. Surg Endosc 11(2):133-138

74. Savader SJ, Lillemoe KD, Prescott CA, Winick AB, Venbrux AC, Lund GB et al (1997) Laparoscopic cholecystectomy-related bile duct injuries: a health and financial disaster. Ann Surg 225(3): 268-273

75. Hospital Episode Statistics 2009-2010. Available at: http://www.heso nline.nhs.uk/Ease/servlet/ContentServer?siteID=1937\&categoryID= 215. Accessed 20 Oct 2011

76. Gurusamy KS, Samraj K, Ramamoorthy R, Farouk M, Fusai G, Davidson BR (2010) Miniport versus standard ports for laparoscopic cholecystectomy. Cochrane Database Syst Rev (3):CD006804

77. Laparoscopic injury study and risk management review for general surgery 2000. Exhibit 6: Rockville, MD: Physician Insurers Association of America; 2000

78. Kern KA (1997) Malpractice litigation involving laparoscopic cholecystectomy. Cost, cause, and consequences. Arch Surg 132(4): 392-397 discussion 397-398

79. de Reuver PR, Wind J, Cremers JE, Busch OR, van Gulik TM, Gouma DJ (2008) Litigation after laparoscopic cholecystectomy: an evaluation of the Dutch arbitration system for medical malpractice. J Am Coll Surg 206(2):328-334

80. Kienzle HF (1999) [Malpractice in laparoscopic cholecystectomy. Results of cases recently considered by the Expert Commission]. Zentralblatt fur Chirurgie 124(6):535-541. Arztliche Behandlungsfehler bei der laparoskopischen Cholezystektomie.
Ergebnisse der gutachterlichen Bearbeitung der von der Kommission behandelten Falle laparoskopischer Cholezystektomie

81. Alkhaffaf B, Decadt B (2010) 15 years of litigation following laparoscopic cholecystectomy in England. Ann Surg 251(4): $682-685$

82. The National Health Service Litigation Authority Report and Accounts 2010-2011: the stationery office; 2011

83. Physician Insurers Association of America Laparoscopic Procedure Study: Rockville, MD: Physician Insurers Association of America; 1994

84. Carroll BJ, Birth M, Phillips EH (1998) Common bile duct injuries during laparoscopic cholecystectomy that result in litigation. Surg Endosc 12(4):310-313 discussion 314

85. Roy PG, Soonawalla ZF, Grant HW (2009) Medicolegal costs of bile duct injuries incurred during laparoscopic cholecystectomy. HPB (Oxford) 11(2):130-134

86. Chandler JG, Voyles CR, Floore TL, Bartholomew LA (1997) Litigious consequences of open and laparoscopic biliary surgical mishaps. J Gastrointest Surg 1(2):138-145 discussion 145

87. Griffen FD, Stephens LS, Alexander JB, Bailey HR, Maizel SE, Sutton BH et al (2007) The American College of Surgeons' closed claims study: new insights for improving care. J Am Coll Surg 204(4):561-569

88. Carroll BJ, Friedman RL, Liberman MA, Phillips EH (1996) Routine cholangiography reduces sequelae of common bile duct injuries. Surg Endosc 10(12):1194-1197

89. Scurr JR, Brigstocke JR, Shields DA, Scurr JH (2010) Medicolegal claims following laparoscopic cholecystectomy in the UK and Ireland. Ann R Coll Surg Engl 92(4):286-291 